\title{
Schopenhauer em Signos: maquinismo e livre-arbítrio no magnetismo do amor
}

\author{
Schopenhauer in Signos: machinery and free will in the magnetism of love
}

\section{Roberto da França Neves*}

Resumo: A publicação da obra de contos de Signos, de Nestor Victor, em 1897, refletiu o impacto da filosofia de Schopenhauer no Brasil do século XIX. O filósofo, que era lido e admirado no mundo inteiro, foi conhecido, no Rio de Janeiro, por um artista que destacou o seu grandioso mérito e meditou com maturidade sobre o conceito de vontade em relação ao amor, nos anos 189o, tendo como referência a obra Metafísica do Amor. Neste ảrtigo, investigaremos a presença da filosofia nos contos victorianos. O poeta Cruz e Sousa chegou a definir o sistema schopenhaueriano através do maquinismo do relógio. Victor desenvolve narrativas que se opõem ao maquinismo dos deveres amorosos para a conservação da vida. No universo de Signos, ao levar em conta a verdade sobre a natureza, revelada pelo filósofo, os seres humanos caprichosamente não mais se encontrarão, já que a paixão se esgota no tédio das obrigações.

Palavras-chave: Nestor Victor; Filosofia; Literatura Brasileira; Schopenhauer; Contos Simbolistas

Abstract: Signs, a volume of short tales by Nestor Victor, was published in 1897 and reflects the impact of Schopenhauer's philosophy in late XIXth Brazil. Widely known and admired, Schopenhauer was read in Rio de Janeiro by an artist who stressed the philosopher's merit and who meditated on the conception of truth towards love, back in 189o's, having as a reference Schopenhauer's Metaphysics of Love. In this article, it'll be investigated the presence of philosophy in short tales written by N. Victor. For Cruz e Sousa, schopenhauerian system could be defined in terms of clock machinery. In this way, N. Victor develops narrative forms that present themselves in oppositional relation towards the duties concerned with preservation of life. In the fictional universe of the volume, human beings don't find existentially themselves, since passion fades away as long as boredom pops up intimately related to the very idea of duty:

Keywords: Nestor Victor; Philosophy; Brazilian Literature; Schopenhauer; Symbolist fiction

\section{Ressonâncias de Schopenhauer:um apaixonado pela liberdade na Belle Époque brasileira}

Nestor Victor (12/04/1868-13/10/1932), paranaense de Paranaguá, foi um autor brasileiro do final do século XIX que refletiu em suas produções o contato com uma série de grandes escritores de seu tempo e com o cruzamento de estilos artísticos e movimentos culturais. Engajando-se vez ou outra na esfera política, teve o seu destino definitivamente conduzido para os assuntos da literatura, a partir do momento em que fixa residência no Rio de Janeiro, em 1891, e passa a conhecer o poeta Cruz e Sousa. Trazemos a lume o seu volume de contos, Signos (1897), seu primeiro livro publicado, que já comprova a sua interação com diversos expositores do pensamento literário, filosófico e artístico, como Friedrich Nietzsche, Arthur Schopenhauer, Villiers de L’Isle Adam, Stéphane Mallarmé e Cruz e

\footnotetext{
* Mestre em Literatura Comparada e Literatura Brasileira em pela Universidade Federal do Rio de Janeiro, Rio de Janeiro, RJ. Professor na rede Fundação de Apoio à Escola Técnica. E-mail: roberto.talassa81@gmail.comORCID: http://orcid.org/o000-0003-0445-2189
} 
Sousa ${ }^{1}$. Entre tantas novidades, o fascínio da arquitetura, as extravagâncias da decadência, o deslumbre da pintura e da música, que pairaram na mente do nosso autor, a novidade de tornar-se um exímio leitor de Schopenhauer nos anos 189o, o que deve fazê-lo respeitado por uma irradiar uma visão lúcida e apaixonada das obras do filósofo no Brasil.

Através de um poema escrito por Victor em 1888, seu principal biógrafo, Andrade Muricy, oferece-nos a imagem de "um inquieto provinciano de 20 anos" ${ }^{2}$. Através de outro poema, esse de 1891, faz-nos reconhecer um "irriquieto sensitivo e irremediável intelectual"3. Era um jovem que gostava de estudar: "Nestor Victor absorvia literatura intensamente" todavia a literatura não era apenas um entretenimento, mas o arauto dos seus anseios de liberdade. Mais tarde, outro grande crítico brasileiro, Alfredo Bosi, veria nesse autor de contos e de poemas "a sensibilidade vibrátil" 5 , que pode ser uma vocação para as energias tenebrosas que se opõem à grande Vontade que rege o universo. Massaud Moisés também consegue perceber nele um intelectual insatisfeito com o aprisionamento da arte, o que nos vai parecendo aos poucos o sintoma de um ímpeto mais profundo de liberdade, que deve tocar as bordas do pensamento filosófico: "Insatisfeito com a aplicação mecânica dos conceitos estéticos, procura levar mais longe a sondagem no organismo social ${ }^{6 ”}$.

Os movimentos finisseculares, Decadentismo e Simbolismo, fincaram uma bandeira em defesa das experiências de liberdade, no campo da estética, mas também no campo da reformulação dos valores humanos. Henri Peyre7, acerca dos escritores excêntricos do Simbolismo, deixa uma declaração sobre a busca particular de liberdade deles, aguçando o tema para muito além de meros estereótipos: "O mais verdadeiro mérito do Simbolismo é ter feito soprar sobre uma literatura prisioneira do real, da descrição do presente ou da pesada evocação arqueológica do passado, um grande vulto de liberdade"8. É imprescindível reverenciar nesse sentido o trabalho contemporâneo de Michel Winock ${ }^{9}$, que apresenta o contexto cultural de uma série de escritores franceses que se engajaram na política e se aproximaram do discurso literário. Eles defenderam, no século XIX, os modos de liberdade como princípio, ao ingressar em diversas correntes do pensamento político e atuar ativamente na sociedade. Victor absorve não somente as obras desses autores, como também todo um conjunto de biografias que procuravam resistir às formas de opressão. Nós compreendemos que seus contos são o reflexo da ânsia de uma liberdade que potencializa a luta contra a opressão, seja mascarada pelo padrão moral burguês, seja pelo espírito científico.

O clássico $O$ mundo como vontade e representação, de Arthur Schopenhauer (17881860), exerce fascínio sobre Victor, que o torna livro de cabeceira ${ }^{10}$. Naquele tempo, os jovens intelectuais foram seduzidos por ideias que colocavam em xeque o livre-arbítrio humano e passaram a vislumbrar uma liberdade sobre bases filosóficas que desconfiassem do simplismo dos sentimentos e dos idealismos. Afirma-se, então, um novo conceito de vontade, ou de ímpeto que nos move a ação, ao determinar a força cega da natureza humana nas escolhas dos seres; por trás dos fenômenos, há uma multiforme referência de

\footnotetext{
${ }^{1}$ Cf. MURICY, O símbolo à sombra das araucárias, 61-186.

${ }^{2}$ MURICY, O símbolo à sombra das araucárias, 96.

3 MURICY, O símbolo à sombra das araucárias, 118.

4 MURICY, O símbolo à sombra das araucárias, 114.

5 BOSI, História concisa da literatura brasileira, 333.

${ }^{6}$ MOISÉS, História da literatura brasileira: Simbolismo, 147.

7 Cf. PEYRE, A literatura simbolista.

${ }^{8}$ PEYRE, A literatura simbolista, 56.

${ }^{9}$ Cf. WINOCK, As vozes da liberdade: os escritores engajados do século XIX, 2001.

${ }^{10}$ MURICY, O símbolo à sombra das araucárias, 114-5.
} 
causalidades que não pode ser apreendida em sua totalidade. Por ser escravo de uma energia que não se pode conhecer totalmente, restaria uma única alternativa para o ser consciente: a renúncia da vontade, mais exatamente, da vontade pessoal. Tendo acesso a esses pontos principais dessa filosofia, o autor de Signos, um leitor consciente e dedicado do mestre, constrói uma ficção em que o próprio amor se torna vítima, por ser a experiência fatal dessa renúncia. $\mathrm{O}$ amor como prisão, refletindo a ausência de liberdade em relação a tudo no universo, constitui o anseio de liberdade mais extremo, uma vez que seus contos reverberam a rejeição das aproximações humanas.

Desse modo, Signos é, antes de maiores considerações, um diálogo indireto mas franco com Arthur Schopenhauer, mais precisamente, com a obra Metafísica do Amor. É, sobretudo, uma reflexão dessa obra na juventude francesa e mundial sob a forma da literatura ficcional. Para Victor, isso não foi uma devoção passageira: décadas depois, em 1921, na obra Elogio do Amigo, ele vai repetir algo que confirma as mesmas meditações filosóficas dos anos 1890: "Assim, em última análise, o que predomina geralmente no homem é o instinto reprodutivo" ". Devemos ter em mente que as principais obras críticas sobre Simbolismo sinalizam a repercussão do sistema schopenhaueriano sobre as angústias e divagações dos jovens decadentes nas últimas décadas do século XIX, esperançosos por compreender as razões últimas da vida.

A respeito da presença de Schopenhauer em Signos, especificamente a sua Metafísica do Amor, precisamos retomar Mikhail Bakhtin ${ }^{12}$, tendo em vista a sua análise sobre a construção híbrida do discurso literário da prosa. Para ele, o valor desse discurso estaria no conserto das vozes dos agentes das diversas camadas representantes da estratificação do pensamento social. Ou seja, o bom autor deve confluir e dosar as vozes (inclusive a sua), de modo todo especial, de acordo com a sua genialidade, diante da angústia de encontrar uma verdade que não seja apenas a sua. Com essa expectativa, esperamos evidenciar nos contos de Victor o concerto de um narrador da prosa, na tentativa de inserir vozes diferentes, até mesmo antagônicas ao conceito de vontade schopenhaueriana, e conferir uma harmonia entre elas. Ou seja, não esperamos transmitir a impressão de que sua ficção é uma tese ou comprovação de uma verdade filosófica. Ao contrário, o leitor deve estar preparado para lidar com o fragmento da filosofia de Schopenhauer e a desilusão dessa verdade tão devastadora (além de outras verdades; inclusive o filósofo Nietzsche pode também ser notado na obra). O narrador chegará ao absurdo de manipular o tema da negação absoluta do amor sexual e das aproximações entre os seres humanos como uma praga de demônios, o que também refletir a presença de uma voz contrária ao ascetismo filosófico, que prega a negação da Vontade.

É importante enfatizar a natureza não retórica do discurso literário, a fim de evitarmos tanto o erro de tornar a obra literária uma tese, quanto de tomar o postulado filosófico como uma crença do seu ilustre leitor. Tentaremos, agora, abrir uma porta para a compreensão dos contos de Victor e da sua transgressão primordial: a não aceitação do mecanismo, ou melhor, do maquinismo da natureza, que rege as relações de amor no universo.

\section{Arthur Schopenhauer no Brasil e no mundo}

"VICTOR, O elogio do amigo, 42.

${ }^{12}$ Cf. BAKHTIN, Questões de literatura e estética. 
Arthur Schopenhauer propagou durante o século XIX o conceito filósofo de vontade, muito mais complexo e profundo que o emprego comum do termo e o tratamento dado anteriormente por outros pensadores. Ele foi responsável por retirar desse conceito uma aura de iniciativa do próprio sujeito, como se o movimento das intenções e objetivos do ser no universo começasse na ação em si mesma e pertencesse unicamente a ele. Nessa direção, vale a pena retomar a definição de Thomas Mann para a vontade, que é a substância primordial do universo e não possui causa: "A coisa em si era a vontade. A vontade era o fundo primordial último e irredutível do ser, era a fonte de todos os fenômenos, era o engendrador e produtor de todo o universo visível e de toda a vida, presente e atuante em cada um dos fenômenos, pois era a vontade de viver"13. Todavia, há uma possibilidade de reversão desse quadro, uma espécie de redenção para o ser na consciência ética, a partir do instante em que toma conhecimento da soberania da vontade e entra em rebelião contra ela:

Como da vida, a qual era inteiramente vontade de viver, podia sair a negação da vontade? Isso resultava possível precisamente porque o mundo era o produto de um ato de vontade, e porque tal ato podia ficar invalidado e suprimido por um ato negativo, por um ato de contravontade. Essa era a façanha de do conhecimento liberado, que, numa espécie de rebelião cósmica dos escravos, emancipava-se da vontade e negava obediência. ${ }^{14}$

Em face da razão que preconiza a liberdade da vontade, o filósofo vislumbra o homem como único ser dotado da capacidade de ser livre (pela autonegação) e assim reconhece a contradição no sistema:

Daí o ensinamento geral sobre o modo como o homem se distingue entre todos os fenômenos da vontade: só nele, com efeito, a liberdade, a independência em face do princípio da razão suficiente, atributo reservado à coisa em si e que repugna ao fenômeno, tem no entanto possibilidade de intervir até no fenômeno; de uma só maneira, é verdade: exibindo uma contradição do fenômeno consigo mesmo. Neste sentido, já não é só a vontade em si, é também o homem que merece o nome de livre, e isso coloca-o à parte de todos os outros seres (W I, §55, 303).

Esses podem ser considerados os elementos fundamentais da vasta obra do filósofo, os quais foram usados por Nestor Victor para a sua meditação particular e para a confecção dos Signos. Em todo o caso, a vontade não pode ser interpretada como algo independente do ser, pois este, embora não seja uma essência individual de ações com propósito no universo, agrega-se a ela e ao todo: "Toda coisa é, por um lado, fenômeno, objeto, e, nesta qualidade, ela é necessidade, por outro, em si, ela é vontade, e, como tal livre para toda a eternidade" (W I, §55, 302).

O filósofo teve grande repercussão dentro dos círculos de autores simbolistas no final do século XIX. Dissemos acima que os críticos e teóricos do Simbolismo, no século XX, fazem alusão a sua participação na formação intelectual dos artistas. Peyre prefere destacar o ímpeto de subjetividade, a partir da perspectiva de que a consciência humana apreende a essência da substância incognoscível que move o universo. Por isso, afirma-se que todo o sistema de fenômenos só pode se realizar na representação do indivíduo, o que parece ter agradado aos jovens intelectuais que desconfiavam dos ditames do cientificismo: "Repetiram, além disso até a saciedade, uma fórmula emprestada a um título e a algumas

\footnotetext{
${ }^{13}$ MANN, Schopenhauer, 29.
}

${ }^{14}$ MANN, Schopenhauer, 41. 
frases de Schopenhauer: o mundo é a minha representação"15. O crítico também detecta a presença do filósofo no romance $A$ Rebours, de J.K. Huysmans, marco da literatura decadentista: "Ele quis sair desta prisão materialista, libertar-se do pessimismo schopenhaueriano em moda"16. Em moda entre os decadentes, o mestre pode não ter sido seguido por um ou outro, como Jules Laforgue, que "escolheu como seu mestre no pensamento, não Schopenhauer, então em moda, mas Edouard von Hartmann, cuja Filosofia do inconsciente, surgida em 1869, fora traduzida em $1877^{\prime 17}$. Como muitos outros, o poeta português Camilo Pessanha também mantinha traços do filósofo, principalmente os aspectos pessimistas da servidão humana diante de uma vontade que transcende às ilusões da presença física e temporal: "Pessanha vê a humanidade poluída depois da queda: um desconserto para o qual não existe esperança alguma de salvação. Seu homem é escravo, schopenhauerianamente prisioneiro da dor"18. Desmistificando os idealismos e a identificação plena da realidade nos quadrantes da pura representação, Guy Michaud destaca o horror e a crueza da vida no personagem Des Esseintes: "Filosoficamente, ele compartilha o pessimismo de Schopenhauer; ele ama suas ideias sobre o horror da vida, sobre a estupidez do mundo, sobre a inclemência do destino"19.

Durante o apogeu dos movimentos decadentistas e simbolistas na França, era Schopenhauer celebrado nos círculos wagnerianos, já que se interessou pela arte em geral, tendo produzido textos filosóficos sobre a música ${ }^{20}$. Sendo Wagner também muito influente nos círculos simbolistas, é reconhecido que o filósofo alcançou os autores de literatura a partir desse interesse que os jovens tinham pelo músico. Essa atmosfera foi de certa forma imitada no Brasil. Cruz e Sousa, em 1891, demonstra no poema em prosa "Volúpia..." a degustação do nome do filósofo na roda de amigos decadentistas em meio à sublimação da música, no momento em devaneava a reunião das diversas artes numa única substância: "Quisera estar agora (...) ouvindo a sonoridade da água que desce das brumas e ouvindo músicas aristocráticas, sonatas convulsivas e dolentes e místicas de Bethoven (...) comentar Schopenhauer, dentre um fundo contemplativo de bruma germânica..." ${ }^{21}$. Com isso, temos a certeza de que a filosofia ganhava espaço em nossa terra naqueles anos do século XIX.

Os raios vigorosos de Metafísica do Amor nos contos de Signos podem ser facilmente observados. A particularidade da filosofia especificamente contida nessa obra foi mencionada por Cruz e Sousa nos artigos-folhetim, divulgados em 1897, como fomentadores das histórias. Ele exatamente nos esclarece sobre o impulso da reprodução dos seres como a essência da Vida, impulso esse disfarçado de amor, e com isso nos oferece o aporte necessário para a correlação entre os contos e a filosofia:

Porque mesmo, no fundo da grande Causa, todos os encantos, todas as graças e atrativos de que se reveste um casal que mutuamente se impressiona na vida, são simples e instintivamente para o efeito da função fisiológica, são seduções apenas para encobrir de vagos véus aparentes e sugestivos o sentimento sexual da procriação da espécie ${ }^{22}$.

\footnotetext{
15 PEYRE, A literatura simbolista, 56.

${ }^{16}$ PEYRE, A literatura simbolista, 68.

${ }^{17}$ PEYRE, A literatura simbolista, 68.

${ }^{18}$ PEYRE, A literatura simbolista, 96.

${ }_{19}$ MICHAUD, Message Poétique du Symbolisme, 251.

${ }^{20}$ Cf. MICHAUD, Message Poétique du Simbolisme, 257-8.

${ }^{21}$ CRUZ E SOUSA, Obra Completa, 713.

${ }^{22}$ CRUZ E SOUSA, Obra Completa, 798-9.
} 
Em seguida, com o tom melancólico, descortina aos leitores essa assombrosa realidade metafísica da Preservação da Espécie disfarçada nos indomáveis sentimentos de aproximação com o outro ser: "triste sonho genésico que alimenta e embala, consolando, a cismadora e aflita raça humana" 23.

O texto de Metafísica do Amor chegou ao Brasil em 1887, através de uma edição em português e teve divulgação na revista $A$ semana ${ }^{24}$. O livro era Pensamento e Fragmento: Metafísica do Amor - Esboço sobre as mulheres, pela editora Laemmert, com tradução de Manuel Coelho da Rocha. Parece ter dado logo bons frutos, pois logo Cruz e Sousa publicou vários poemas que dão mostras de que Schopenhauer era lido e compreendido no início dos anos 1890. O poema em prosa "Croque dum excêntrico" registra a existência de uma típico personalidade decadente, destoada das massas, que absorve "esse pessimismo torturante por vezes nos livros de Schopenhauer e Hartmann"25. Percebe-se o registro do "pessimismo" no círculo de escritores de literatura. "Doença Psíquica", outro poema do mesmo tipo, trazia uma concepção mecanicista do pensamento do filósofo: "Para ti, Schopenhauer , a existência é a materialidade, o alimento, para ti é apenas a necessidade de prevalecer na luta, a força para a função dos órgãos nervosos, a bem de que se propague a espécie”. Logicamente, o nosso poeta, preso às forças do tempo, pode ter dado uma interpretação mais materialista e naturalista dos escritos filosóficos que lhe chegaram às mãos. Como dissemos, ele concebeu pela metáfora do maquinismo do relógio o sistema difundido por Schopenhauer: "Basta para ti, que o estômago metodicamente funcione, na normalidade cronométrica de um relógio, a fim de que tenhas a positiva segurança de que subsiste aos vermes" ${ }^{26}$. Essa leitura feita por Cruz e Sousa certamente foi compartilhada com Nestor Victor, pois são muitos os depoimentos acerca dos contatos que eles mantinham entre si, como esse de Andrade Muricy: "Com o pintor Maurício Jubim e com o intelectual cearense Tibúrcio de Freitas, Nestor Victor integrava o grupo mais íntimo do poeta dos Broquéis"27. Os constantes encontros tinham o objetivo de proporcionar-lhes o amadurecimento intelectual. São muitas as palavras que evocam o carinho de um discípulo que reconhece o seu professor, em relação à Cruz e Sousa: "Confessava que nenhuma amizade pudera proporcionar-lhe o alimento substancioso, o alto inebriamento espiritual que lhe valia o trato com o Poeta Negro" 28

A propósito do maquinismo da Vontade em relação às espécies, destaco a tese de Luan Corrêa da Silva ${ }^{29}$, que comenta o conceito de amor em coerência com todo o sistema filosófico de Schopenhauer. Ele ressalta o trabalho inconsciente do indivíduo para a espécie, ao visar à continuidade e ao melhoramento da mesma; com isso a abstrata Ideia se converte na aparência, através dos fenômenos. Aprofundando-se, o pesquisador detecta a desmistificação do caráter romântico do amor, através da ilusão que o indivíduo possui, ao considerar o aspecto individual como se fosse eterno. A raridade desse amor romântico é um caso à parte em relação ao amor sexual e parece um milagre quando eles se identificam um com o outro: "E sua raridade aparece no autêntico amor apaixonado, em que duas pessoas formam uma conexão quase milagrosa, em uma adequação que por vezes espanta em sua perfeição" ${ }^{30}$. Essa concepção de atração motivada por sentimentos puros e desinteressados não passa de uma ingenuidade rara e fantasiosa. O recente trabalho de Valci Vieira dos

\footnotetext{
${ }^{23}$ CRUZ E SOUSA, Obra Completa, 798-9.

${ }^{24}$ Cf. BOTTMANN, Arthur Schopenhauer no Brasil (1887-2015). Revista Belas Infiéis, 251-9.

${ }^{25}$ CRUZ E SOUSA, Obra Completa, 688.

${ }^{26}$ CRUZ E SOUSA, Obra Completa, 725.

${ }^{27}$ MURICY, Panorama do Movimento Simbolista Brasileiro, 337.

${ }^{28}$ MURICY, Panorama do Movimento Simbolista Brasileiro, 337.

${ }^{29}$ Cf. SILVA, Metafísica prática em Schopenhauer,101-24.

${ }^{0}$ SILVA, Metafísica prática em Schopenhauer, 107.
} 
Santos $^{31}$, ao caracterizar a tragédia burguesa do século XIX, também aponta para o amor desmistificado de Schopenhauer, como uma verdade maldita que teria dado a sensação de esgotamento da humanidade: "Até mesmo o amor, isto é, a metafísica do amor, é analisada de um ponto de vista pragmático, em que as pessoas se aproximam uma das outras com objetivos específicos. (...) o resultado desse amor é o trágico amor infeliz, decepções do amor satisfeito, consciência amorosa trágica, portanto"32. A partir do momento em que a humanidade toma a consciência filosófica dessa desconexão entre amor e sexo, a arte adianta-se para expor a tragédia de um universo sem amor ou sem sexo. A divergência entre o amor sexual e o amor romântico é o ponto de partida para o entendimento dos Signos. Agora, é importante que se tenha em mente que não há espontaneidade no amor porque não há liberdade individual.

A partir da filosofia, temos o conhecimento, como o velho fruto da árvore do conhecimento, de que liberdade é dada como uma ilusão que seduz o ser a subordinar-se ao domínio incompreensível da vontade: "Cada um julga-se a priori absolutamente livre, e com isso em cada um dos seus atos, isto é, crê que pode a todo momento mudar o curso da sua vida, ou seja, tornar-se um outro" (W I, §23, 122). Trata-se de um impulso falso que será desmascarado a partir da reflexão; é a Vontade que comanda tudo: "É apenas a posteriori, após experiência, que ele constata, para grande espanto seu, que não é livre, mas está submetido à necessidade; que apesar dos seus projetos e das suas reflexões, ele não modifica em nada o conjunto dos seus atos, e que, de uma ponta à outra da sua vida, ele deve revelar um caráter que não aprovou e continuar um papel já começado (W I, §23, 122-3)”.

Segundo Leandro Chevitarese, o livre-arbítrio individual é falso, pois a liberdade pertence somente à energia indecifrável da vontade universal: "Há uma explícita rejeição ao que se convencionou chamar de "livre-arbítrio". Somente a vontade tomada como coisa em si pode ser livre. $\mathrm{O}$ que fundamentalmente somos não pode mudar - o caráter empírico é apenas uma expressão variada do imutável caráter inteligível. Não há, portanto, liberdade para as ações individuais" 33 . Desse modo, o ser é livre, apenas no sentido de manifestar a liberdade da vontade que transcende aos desejos individuais: "Ninguém é livre para agir, pois todas as ações surgem necessariamente do que se é, mas "o que se é" constitui um ato inteiramente livre. Isso significa que aquilo que fundamentalmente somos, simplesmente "é o que somos", como ato livre, independente de toda necessidade" 34 . Ele fará uma reflexão em torno das possibilidades de ser o que se é. Ele considera, em conformidade com o que já foi aqui dito, que "todos os atos de um homem são a expressão de seu caráter" 35 , contudo "por meio do autoconhecimento o indivíduo pode melhor interpretar seu papel no cenário do mundo, no teatro da vida" ${ }^{36}$. Se prosseguirmos nessa tentativa de libertação da Vontade, haveria uma única maneira de liberdade, quando o indivíduo se livra das correntes da necessidade e rompe as cadeias da vontade transcendente, segundo Kátia Santos: "O ato de negação da Vontade se nos apresenta como uma ação livre no âmbito da própria

\footnotetext{
${ }^{31}$ SANTOS, Tragicidade nas poéticas de Cesário Verde e Cruz e Sousa, 58-9.

${ }^{2}$ SANTOS, Tragicidade nas poéticas de Cesário Verde e Cruz e Sousa, 59.

33 CHEVITARESE, A eudemonologia empírica de Schopenhauer: a "liberdade que nos resta" para a prática de vida. Arthur Schopenhauer no Brasil: em memória dos 150 anos da morte de Schopenhauer, 128.

34 CHEVITARESE, A eudemonologia empírica de Schopenhauer: a "liberdade que nos resta" para a prática de vida. Arthur Schopenhauer no Brasil: em memória dos 150 anos da morte de Schopenhauer, 130.

35 CHEVITARESE, A eudemonologia empírica de Schopenhauer: a "liberdade que nos resta" para a prática de vida. Arthur Schopenhauer no Brasil: em memória dos 150 anos da morte de Schopenhauer, 143.

${ }^{36}$ CHEVITARESE, A eudemonologia empírica de Schopenhauer: a "liberdade que nos resta" para a prática de vida. Arthur Schopenhauer no Brasil: em memória dos 150 anos da morte de Schopenhauer, 145.
} 
representação, na medida em que realiza uma ruptura na necessidade da lei de motivação"37. Com isso, deter-nos-emos no conceito relativizado de Vontade, que deve ter, por um lado, surpreendido e assustado os jovens intelectuais impregnados ideias libertárias e, por outro lado, despertado neles o ato mais profundo de aperfeiçoar ou negar essa mesma Vontade e alcançar mais (ou a verdadeira) liberdade. Sobre a ação de o homem negar a vontade em si, para que a vontade ultrapasse o mundo inteligível e alcance o mundo fenomênico, consideramos as palavras de Schopenhauer:

No fim das nossas especulações, aliás, chegaremos a uma conclusão, tornada possível através do conhecimento, no ser que mais perfeitamente manifesta a vontade: esta conclusão é a supressão e a negação dessa mesma vontade; basta que ela dirija sobre ela mesma a luz desse conhecimento. Deste modo a liberdade, ainda que, aliás, relegada para fora do mundo dos fenômenos, na sua qualidade de atributo da vontade, chega contudo, neste último caso a penetrar nesse mesmo mundo: com efeito, ela suprime o ser que serve de base ao fenômeno; e, como este persiste, mesmo neste caso, através do tempo, daí resulta uma contradição do fenômeno consigo mesmo, e assim a liberdade faz vir à luz estes fenômenos, a santidade e abnegação (W I, §55, 303).

É preciso não confundir a liberdade transcendental que move os seres e a liberdade das escolhas permitidas ao indivíduo, ou melhor, "um "resto de liberdade" no domínio dos fenômenos"38. Com isso, esclarece Vilmar Debona que a vontade não se trata de um ventrículo, ao desenvolver uma noção pouca reportada ao filósofo, a de caráter adquirido; com isso, o sujeito que melhor aprimora o autoconhecimento é capaz discernir os melhores caminhos para a realização da sua vida, pois "só com o saber adquirido mediante o comércio com o mundo cada um fica em condições de guiar com clareza de consciência o modo de agir próprio de sua natureza individual"39. Embora o ser possa optar por diferentes maneiras de ser o que se é, impõe-nos a reflexão de uma autossabotagem pela consciência da ditadura da Vontade. Vejamos como as histórias de Signos representam exatamente a reflexão sobre a repulsão ao maquinismo das comunhões humanas e sobre a tragédia de um amor desmistificado.

\section{A voz de Schopenhauer em Signos}

A filosofia schopenhaueriana afirma que o amor não tem causa subjetiva, ou seja, é o reflexo de um imperativo substancial que transcende os idealismos e sentimentos: a necessidade de reprodução e preservação da espécie através do impulso sexual. De certa forma, com a noção de uma transcendência que ocorre apenas nos limites da existência humana, aceitamos a ilusão das paixões como algo verdadeiro em si, conforme o filósofo nos diz no discurso de Metafísica do Amor:

\footnotetext{
37 SANTOS, A liberdade no pensamento de Schopenhauer. Arthur Schopenhauer no Brasil: em memória dos 150 anos da morte de Schopenhauer, 286.

${ }^{8}$ DEBONA, Vilmar. A noção de caráter adquirido: uma "liberdade” pela sabedoria de vida. Arthur Schopenhauer no Brasil: em memória dos 150 anos da morte de Schopenhauer, 225.

39 DEBONA, Vilmar. A noção de caráter adquirido: uma "liberdade" pela sabedoria de vida. Arthur Schopenhauer no Brasil: em memória dos 150 anos da morte de Schopenhauer, 226-7.
} 
O fim último de toda disputa amorosa, seja ela com borzeguim ou coturno, é realmente mais importante que todos os outros fins da vida humana, e, portanto, merece por inteiro a seriedade profunda com a qual cada um o persegue (W II, capítulo XLIV, 8).

Todo sentimento associado ao afeto nada mais é que uma deliberação maquinal do instinto de conservação:

O que por fim atrai com tal força e exclusividade dois indivíduos de sexos diferentes, um para o outro, é a vontade de vida que se expõe em toda a espécie, e que, aqui por uma objetivação de acordo com seus fins, antecipa sua essência no indivíduo que ambos podem procriar (W II, capítulo XLIV, 12)

O público-leitor de Signos, já acostumado ao debate filosófico, deverá reconhecer facilmente a voz do narrador, que se coaduna com o pensamento de Schopenhauer, já são reforçados os apelos da implacável natureza que governa os desejos dos seres conforme o seu interesse. Vem à consciência dos jovens o único motivo do impulso amoroso e com isso a desilusão com qualquer transcendência de outra natureza, humana ou espiritual. O papel que desempenham é determinado e os seres apenas são fantoches de uma substância mais forte. A palavra "Vida da Espécie" no prólogo de Signos representa a única entidade eterna, que molda todos os formatos de vida humana; em itálico, marcamos a condição de escravos da Natureza para conotar a relação entre o ser e o seu compromisso com a Vontade:

Nós somos como o maquinismo dos relógios, que não pode se oxidar na inércia, nem repousar, sequer, na desigualdade de um movimento mais preguiçoso, mais tardo, somos, na realidade, o maquinismo de um deles, cujo quadrante está perpetuamente exposto aos olhos dos homens para eles saberem a que hora se acham na Vida da Espécie, e esse, mais do que os outros, não pode imobilizar os eixos. No instante em que o fizesse se havia de assistir à última ânsia humana, mas como ela é indizível, última angústia da sagrada Esperança na Terra..$^{40}$

Esse prólogo de Signos não é propriamente uma narrativa: sem personagens, sem tempo e espaço, funciona, em relação aos contos seguintes, como uma introdução, em formato de crônica poética. Pode ser classificado como poema em prosa a exemplo dos poemas do Missal, sendo dotado de profundo caráter lírico. $\mathrm{O}$ narrador apela aos leitores sobre os impulsos e dores provocados pelas vicissitudes do amor. A relevância do ato de sofrer se faz argumento para reafirmar a robustez de um caráter forte e genuíno, afinando-se com a voz de $O$ mundo como vontade e representação: "Sofrer e não tirar conclusão, é ser como se fosse inorgânico, é confundir-se com o não ser. A dor não é mais do que o estímulo para o Pensamento. Sofrer é apenas ter a possibilidade de existir" ${ }^{41}$. O seu conteúdo é o contrário de qualquer esperança. Um dado importante é que o sofrimento, que deve fazer frear as experiências amorosas, tem uma única utilidade nesse prólogo, que deve ser lido em conexão direta com os contos: dar-nos sabedoria. Isso está muito relacionado à filosofia: "A dor é o positivo; o prazer é a sua mera supressão, é algo negativo, e se converte em seguida em aborrecimento" ${ }^{2}$. O sofrimento traz todo o pessimismo de um mundo barbarizado pelas

\footnotetext{
$4^{\circ}$ VICTOR, Signos, 4-5.

${ }^{41}$ VICTOR, Signos, 6.

${ }^{42}$ MANN, Schopenhauer, 35 .
} 
experiências negativas do amor, mas deixa ao ouvinte a possibilidade de compreensão da realidade mais oculta para tornar-se sábio.

O narrador de Signos apresenta ainda de modo direto o apelo à tese de Schopenhauer nos primeiros parágrafos do conto "Fatalidades!...”. Reiteramos que ele compreende que o amor é o responsável pela manutenção da vida e da espécie humana, sendo essa a sua única missão objetiva. Acata com total resignação a missão que lhe é enviada, ao entender que as paixões são efêmeras, enquanto a única substância verdadeira é a eternidade dos seres humanos:

Toda esta poesia do Amor, estas longas noites e estas tantas horas perdidas em sonhos e em recordações, estes desejos e estes temores ao mesmo tempo, estes zelos e estas efusões deliciosas, tudo isso, é nada mais, anda menos, que o apanágio de uma realidade prosaica, o tinir dos ferros a que estamos presos, desviando-nos a atenção de nossa sorte, e fazendo-nos assim caminhar para ela com mais precipitação e mais cegueira ${ }^{43}$.

A novidade agora é que fica nítido que todas as histórias de paixão não passam de aparência de algo realmente essencial, em conformidade com as palavras do filósofo.

Todo enamorar, por mais etéreo que possa parecer, enraíza-se unicamente no impulso sexual mais bem determinado, mais bem especializado e mais bem individualizado no sentido rigoroso do termo. Quando, então, sem esquecermos disso, consideramos o papel importante que o impulso sexual desempenha, em todas as gradações e nuanças, não só nas peças de teatro e romances, mas também no mundo real, onde ele, ao lado do amor à vida, mostra-se como a mais forte e ativa das molas propulsoras, absorvendo ininterruptamente a metade das forças e pensamentos da parte mais jovem da humanidade. É ele a meta final de quase todo esforço humano... (W II, capítulo XLIV, 5).

Vê-se novamente a resignação do narrador com as determinações da natureza; e nisso a oportunidade de se inserir no único evento real existente na terra, ainda que seja isso assombroso e pérfido. Em itálico, observamos a mesma condição anteriormente vista de escravos da natureza no ato de procriação para atender aos interesses da espécie:

Chamam-nos para um dos principais serviços que pesam sobre os nossos ombros de escravos. No fim, tudo é para a procriação e pela procriação somente. Instrumentos que somos, desempenhamos o nosso papel, os anos esmagam-nos, e, inúteis como um molde servido, vemos abrir mãos de nós a natureza saciada ${ }^{44}$.

Note que, após sinalizar a tese filosófica em tons melancólicos e resignados, o narrador relaciona o "maquinismo" ao surgimento de seres nefastos, que não querem mais amar, como que contaminados pela moléstia que contamina a humanidade. Em itálico, detectamos a conjunção consecutiva que estabelece o mecanismo do surgimento dos seres insensíveis, os "demônios", aqueles que vão se rebelar contra a Vontade45:

É, por isso, filha, que às vezes, indo felizes, estrada a fora, braços pela cintura, encontramos uns vultos suspeitos, misteriosos, que nos incomodam com

\footnotetext{
43 VICTOR, Signos, 9.

44 VICTOR, Signos, 10.

45 VICTOR, Signos, 10.
} 
insistentes olhares, em que há uma ironia aborrecida, um ar de superioridade que nos irrita.

Estes são os demônios revoltados contra as tirânicas leis do Amor ${ }^{46}$.

Observamos a finalidade dos sentimentos, enfatizada como a verdadeira e única verdade que se manifesta no universo: a procriação, somente a procriação. Então, se o amor está enclausurado pela obrigação das leis da reprodução, os personagens em forma de gracejo inconsciente não deverão mais consumar o amor. Com isso, requer-se a única saída contra o domínio da natureza nefasta, a não ação, a negação da vontade. No entanto, a presença desses "demônios" nos faz afirmar que a obra flutua entre uma consideração positiva ou depreciativa desse aniquilamento da vontade, o que é um caráter flagrantemente literário do discurso de Nestor Victor.

O que o narrador de Victor vai fazer, conto após conto, é construir intrigantes aventuras de "greve de amor" e até de sexo, através de experiências incompletas ou insaciadas de afeto. Se o amor é exatamente isso, o absurdo da transcendência de uma energia oculta que manipula os seres para a geração da Vida (não que discordasse, ou que propusesse tese contrária, uma vez que a proposta poética é diferente da retórica - mas estaria apenas assombrado com relativa verdade), então que gracejosamente os encontros definitivamente não aconteçam e que não haja sexo, nem procriação, nem amor. Que haja uma negação da Vontade, conforme a proposta de Schopenhauer, segundo Kátia Santos, pois "na situação singular da negação da Vontade, ele afirma que um indivíduo pode concretizar a liberdade, ainda que a necessidade seja a condutora do mundo" 47.

A primeira rasura de conceito de Vontade será no conto "Fatalidade!...”. Enquanto na filosofia de Metafísica do Amor tudo estaria organizado para a provisão das espécies, Victor nesse primeiro conto abre espaço para a exceção e para a anomalia, através de um casal indiferente aos sentimentos. Enquanto na obra filosófica o impulso sexual determinará os consórcios para fins de reprodução, no conto o ser mitológico Amor deve assumir a preponderância sobre o impulso sexual, forçando a aproximação do casal, a fim de garantir a manutenção da espécie. Não há efeito: o casal não se encontra em afeto. Como punição, eles se relacionam sem amor, sendo despidos de seus bens. Parece então que o amor (ou o Amor) trai a si mesmo. Com isso, fica realmente provado que não há qualquer necessidade de sentimentos afetivos para a procriação. E é essa a praga que se alastra pelo mundo. Ainda assim, nos contos que sucedem a esse não haverá também sexo, nem qualquer efetiva aproximação entre os seres humanos. Deveria haver pelo menos sexo, "o amor cru, indecente e negro" ${ }^{8}$, mas nem isso haverá mais.

Perceba uma relação. Enquanto no prólogo e nos primeiros parágrafos de Fatalidades!... o narrador ratifica o império da Vontade, o pragmatismo de um mundo que dispensa o afeto, nesse universo ficcional, vai demonstrar o contrário. Os relacionamentos humanos estariam a partir de então esgotados pelo tédio dos deveres com a Natureza. Esse sentimento de tédio, presente em cada conto, deixa de ser um termo comum para ser o ente que faz gravitar, com a força poética, o retorno do velho e bom amor. Assombrado com a tese do impulso sexual que se sobrepuja ao afeto, na revelação de que o amor é uma aparência dessa, digamos, Manutenção da Espécie, o narrador terá o pesadelo de um universo completamente esvaziado de substância.

\footnotetext{
${ }^{46}$ VICTOR, Signos, 10.

47 SANTOS, A liberdade no pensamento de Schopenhauer. Arthur Schopenhauer no Brasil: em memória dos 150 anos da morte de Schopenhauer, 274.
}

$4^{8}$ VICTOR, Signos, 14. 


\section{A reação dos contos ao sistema de Schopenhauer}

O narrador de Signos se apresenta como o homem das noites, o típico viajante do mundo noturno, que sabe fazer serenatas para quem pode ouvir das varandas e talvez conte histórias por meio delas. Cria-se a expectativa de que se cantarão em prosa contos de amor para acalentar o sonho dos jovens ansiosos por histórias românticas:

Escutai-nos. Para nós outros o dia e a noite são de luar. Nós somos os loucos que se enredaram nos filtros do Planeta estranho, cujo âmbar diluído constitui a nossa atmosfera perene, de que vivemos saturados até o âmago, sem as tréguas clementes dos interlúnios. Nossa vida é toda de serenatas sob os arabescos dos vossos varandins dormentes ${ }^{49}$.

Nesse trecho de "AS SERENATAS", uma espécie de prólogo, o seresteiro prepara o espírito do leitor para histórias que seguirão ratificando a autoridade de quem as conta: o seu narrador é aquele que viaja, tem experiência da vida e vem de longe circulando "nos filtros do Planeta Estranho"50 (Ibid., p.3). Benjamin ${ }^{51}$ diz que a narrativa surge da oralidade de homens simples que viajam ou conhecem muito a tradição de seu povo: "E, entre as narrativas escritas, as melhores são as que menos se distinguem das histórias orais contadas por inúmeros narradores anônimos. (...) "Quem viaja tem muito o que contar", diz o povo, e com isso imagina o narrador como alguém que vem de longe”. Ao invés do entusiasmo das novidades trazidas por um peregrino, esse narrador na verdade não deixa de estar esgotado pelo tédio do maquinismo na missão de acalentar as paixões com suas histórias musicais, visto que ele tenta suportar o tédio, entre aqueles que estão "saturados até o âmago, sem as tréguas clementes dos interlúdios" ${ }^{2}$. É nesse clima fantasioso de aborrecimento e angústia que ouviremos as histórias que deliciarão os nossos desejos de compreensão do mundo.

Vejamos "Hirânio e Garba". Nesse conto, observa-se a temática da transgressão fundamental, o pecado original dentro de uma cidade ou civilização: dois jovens rompem com a tradição dos antepassados, tornam-se anátemas e são condenados ao isolamento, à privação de alimentos e à morte. Isso ocorre quando o mancebo burla as leis que regem a socialização entre moços e moças na cidade de Morkoma e resolve se aproximar um pouco de uma moça, muito admirada, Garba. O rapaz, então, torna-se a imagem do terror e da deformação do homem, o monstro Anarquia, a quem todos deveriam desprezar e evitar o mais íntimo contato. A moça, por compaixão e amor ao admirador, acaba cedendo aos impulsos do amor; os dois se unem e atraem contra si a rejeição da sociedade. O amor tenta reagir como algo que não se impõe pela lei, contudo o elo esperado não acontece, visto que os dois morrem no deserto privados de alimentos.

Então, os jovens que cederam ao ímpeto do amor, à voz da naturalidade dos sentimentos, foram a chama que se apaga diante da sociedade legalista, a "terra das fórmulas

\footnotetext{
49 VICTOR, Signos, 3.

$5^{\circ}$ VICTOR, Signos, 3.

${ }^{51}$ BENJAMIM, O narrador. In: Obras escolhidas: Magia e técnica, arte e política, 198.

$5^{2}$ VICTOR, Signos, 3.
} 
e das convenções" 53, onde "ninguém dava um passo sequer que não o subordinasse a um metro estabelecido" 54 , país que regula o matrimônio pelas leis: eis a luta da espontaneidade contra o maquinismo no tema do amor e das afinidades. As leis da cidade acabam por se tornar uma representação do maquinismo da Vontade que determina a comunhão dos seres. Os jovens sucumbem representando o fim do amor verdadeiro, aquele que nasce do sentimento e se caracteriza pela espontaneidade, pelo desejo de romper com o senso de cumprimento do dever.

O conto "Agonias" faz crítica feroz à artificialidade da religião. A história tenta mostrar a impossibilidade de harmonia entre o viver honesto segundo os sentimentos e os deveres do sistema, através do comportamento de clérigos hipócritas e de um bom padre que está em vias de falecer. Na trama, os padres Manuel, Hipólito e Samuel passam apressadamente pela multidão e se dirigem ao local onde está o padre Honório, que agoniza à espera da morte, para prestar-lhe as últimas assistências sacramentais. $\mathrm{O}$ moribundo é um sacerdote íntegro, portanto sua agonia e morte se cristalizam como símbolos da derrota dos bons e da pureza da espiritualidade num universo governado pelos interesses do pragmatismo e da ganância. Os demais padres, ambiciosos, representam, por outro lado, a vitória dos maus instintos e de uma religiosidade nefasta, que não se importa com os anseios populares. Vence, portanto mais uma vez, a máquina, ou melhor, o sistema da religião como instituição social contra a iniciativa pessoal da bondade. $O$ enredo está inserido num contexto de crítica social ao comportamento de clérigos pelos jovens republicanos 55 .

Notemos os traços que estilizam o maquinismo e o livre-arbítrio. O padre Honório morre solitário na presença de sacerdotes nefastos que mais parecem seres malignos; tal fato alicerça a solidão do moribundo e a própria solidão simbólica de tudo que é puro e não está condicionado ao sistema (clerical): "Veio o mesmo grupo de padres, cercaram o esquife de batinas pretas, levantaram-no da eça, e ele seguiu, como uma presa rodeada de asas negras que batem" ${ }^{56}$. Nota-se que o termo "presa", referido ao padre bom conduzido pelos maus, está em conformidade com tudo que fundamenta a derrota da espontaneidade frente à crueldade do pragmatismo e da subordinação ao maquinismo da vida. A história também insiste no caráter solitário do nosso herói sem uma audiência verdadeira, que atentasse para as coisas pertinentes à espiritualidade neste mundo decadente: "Que veio muito tarde. Faltou-lhe o apoio; o mundo não tinha fé. Agiu no vácuo, porque ninguém ouviu o que ele disse. Com seus anos viu multiplicarem-se os maus, quando ele só trabalhava para multiplicar os redimidos"57. Os apelos do padre para a manifestação pura e espontânea do sentimento, sem o legalismo e o artificialismo das regulamentações eclesiásticas, foram vencidos: "enquanto vivera, vivera com ele a Religião" 58.

"O Máscara” é o conto que tematiza a hipocrisia nas relações sociais e nas amizades, através do vício das imposições do hábito de interagir com conhecidos e de dispensar o contato com desconhecidos. O narrador, que surge sem a companhia de um amigo num dia de carnaval, ou como ele próprio diz "sofrendo comigo o meu tédio" 59 , sente-se importunado por um gracioso desconhecido que vem papear com ele. Ao tentar despachar o estranho, fica impressionado com a sua perspicácia para a especulação filosófica acerca das relacionamentos sociais. Com isso, ele vai perdendo a desconfiança natural que se tem de

\footnotetext{
53 VICTOR, Signos, 15.

54 VICTOR, Signos, 15.

55 Cf. MURICY, O símbolo à sombra das araucárias, 88-91.

${ }^{6}$ VICTOR, Signos, 29.

57 VICTOR, Signos, 29.

$5^{8}$ VICTOR, Signos, 29.

59 VICTOR, Signos, 33.
} 
estranhos nas ruas, ao mesmo tempo em que se vê iluminado com as reflexões que tocam a causa da interação entre os seres humanos. De fato, os seus amigos não se importam com ele e não procuram a sua companhia. No fim, o desconhecido desaparece subitamente, provando que nesse universo ficcional os pares não se encontram para qualquer finalidade, por conta das artificialidades das leis e hábitos que regem a natureza humana e social. Desse modo, a rotina e o tédio das mesmas coisas tomam o lugar da iniciativa abortada do afeto espontâneo: "Eu fiquei sozinho, diante de um cálice de conhaque, que mandei vir depois disto, e aos poucos me fui mergulhando no meu tédio, de novo, pensando comigo que aquele pobre diabo, com tais preocupações, com certeza não passava de um triste poeta"6o.

"Olvério" é uma história de amor ambientada em reinos e tempos distantes do leitor brasileiros, na qual deve vislumbrar o fracasso da ação espontânea para a paixão bemsucedida. O jovem príncipe, insatisfeito com os aparatos de bajulação da corte, foge do reino disfarçado de homem comum, a fim de obter uma vida real, sem a pressão das obrigações. No fundo, talvez desejasse saber se as pessoas o amavam por suas qualidades inatas ou pela imposição da lei. Posteriormente, apaixona-se por uma moça virtuosa, Fenema, que a princípio corresponde ao seu amor, mas em seguida desiste de ter esperanças com ele por ouvir os conselhos desconfiados da família. O rapaz, muito apaixonado, vê-se então obrigado a revelar a verdade sobre a sua origem para que ela, conhecendo o príncipe disfarçado naquele jovem simples, correspondesse às suas investidas. Por fim, se descobre que ali as relações apenas existem infelizmente por causa da força impulsora das obrigações naturais. O príncipe, ao verificar que somente foi correspondido por sua identidade, sentese morto de tanto nojo e tédio.

Muitos detalhes nessa narrativa se referem diretamente ao que podemos chamar de maquinismo schopenhaueriano. O tédio entra em cena como o sentimento propulsor da transgressão do príncipe, através da tentativa de superar o conflito: "Desde cedo aborreceuse o moço daquela triste fabricação de miseráveis que era o seu único ofício. Pudesse ele, e tão indignos costumes de pronto desapareceriam ao seu mando"61. A palavra "fabricação", remetendo-se à produção planejada e serial, apela para a mesma repetição do tédio. De outro modo, o espontâneo morre em si mesmo e o que existe de substância no universo é forçado pelo instinto.

"A Vitória" é uma história que narra a imaginação e os conflitos internos de um jovem rapaz que procura resistir às investidas de uma namoradinha de ocasião e sente-se culpado por arrastá-la a uma paixão à qual não está disposto a corresponder. É mais uma história que está em consonância com tudo que dissemos sobre a invariável do amor não correspondido; é mais uma história sobre a aliança equivocada e fracassada entre o feminino e o masculino, sem resultado promissor, sem que haja um final feliz, sem o equilíbrio do "maquinismo" prometido no prólogo. O conto começa pela constatação e reiteração de resistência do rapaz ao amor da moça: "E a obsessão não o deixava"62, como se estivesse sendo perseguido pela sombra da culpa. De fato, o personagem, acometido de remorso constante, passa a ser tomado pela obsessão, algo que não está relacionado à construção de um amor espontâneo; ele deve vencer a imperiosidade que rege tal obrigação dos sexos opostos para a procriação. Por um lado, a moça se esforçava para conduzir o amante para a sua paixão; por outro, não haveria alternativa para convencer um rapaz completamente desafinado com o relacionamento. Ao vencer a moça a frieza do rapaz, venceria a obediência cega às leis da Natureza que regem o consórcio.

\footnotetext{
${ }^{60}$ VICTOR, Signos, 40.

${ }^{61}$ VICTOR, Signos, 42.

62 VICTOR, Signos, 53.
} 
Como é natural dos clichês românticos, a regeneração da personalidade, ou certa redenção do caráter promovida pela força de vontade da mulher deve por fim vencer a resistência do homem bruto. Ela conseguiria modificar o seu caráter, uma vez que o rapaz deixaria de ser fútil, namoradeiro, um pretenso conquistador de todas, e passaria a conhecer a estabilidade do relacionamento. Então, a moça, que aparentemente teria conduzido o namorado para afinar-se com os seus desejos, vence a resistência masculina ao relacionamento sério, mas nada conquista de fato. Ela, uma vez vencida a resistência do amante, passa a não se interessar mais por ele; os papéis se invertem: ela se torna alheia aos sentimentos da paixão, não vendo mais sentido no relacionamento. Novamente, sempre que um lado espontaneamente se esforça para comover o outro recebe como resposta a ausência da vontade, dando vigor à representação estética da rebelião.

O conto "Humor" trata da autossuficiência de um homem, que muito talentoso e perspicaz, deseja sobressair-se na sociedade e ser louvado por seus méritos profissionais. Ele acredita ter o dom do conhecimento para o melhoramento da civilização e para o bem-estar coletivo. Na história, Dr. Camilo, após retornar de Paris, sente a necessidade de transmitir os valores da civilização europeia, a fim de promover o refinamento dos gostos e da educação da América. Para isso, resolve fazer reuniões em sua residência, com o intuito de dar demonstrações de toda a sofisticação da metrópole francesa; convida parte da sociedade para receber suas instruções e assim fazer propaganda profissional. O doutor, deslumbrado e arrogante, sente-se superior ao seu povo e o seu zelo pecaria pela ausência de afinidade sincera no trato com os seus concidadãos.

O leitor é levado a ver Dr. Camilo como um solitário em seu universo ficcional, assim como os personagens dos outros contos. Numa excelente adaptação moderna da tragicomédia, o conto desenrola-se em cenas engraçadíssimas de desavenças e perturbações entre os convidados na primeira reunião em sua casa. Em suma, as pessoas que frequentam a sua casa não demonstram o menor interesse por sua palestra, não fazem a menor ideia de suas intenções e resolvem até se aproveitar para extorqui-lo. No segundo encontro, a maioria dos convidados decide não visitá-lo por conta de fofocas, intrigas, desprezando as suas instruções. O leitor deve ser levado a se perguntar onde está a sua esposa, uma vez que as mulheres cumprem melhor que os homens o papel de dar sofisticação às relações sociais e recepcionar os convidados de uma reunião. Contudo, há uma tentativa frustrada de aproximação dos seres como nos demais contos: uma senhora naquele local é a única pessoa realmente disposta a prestar atenção aos seus gestos. Essa senhora é surda, o que fundamenta a incompatibilidade do qual estamos tratando desde o início. Dr. Camilo a despreza por sua deficiência, pois ela não é o público alvo de suas requintadas demonstrações. Novamente, sempre que um lado se robustece para atrair o outro, harmonizando as relações de afeto, a indiferença acontece da parte de um deles ou dos dois e os encontros felizes não se consumam.

"Alegria Fúnebre" é a história de um casal muito pobre, um ex-militar negro, que combateu na guerra do Paraguai, e uma velha paraguaia, a quem se uniu em condições precárias. Desenrola-se num contexto de violações da condição humana. $\mathrm{O}$ ex-militar, deficiente, sobrevive graças às esmolas que sua mulher angaria pelas ruas; esta passa por situações de estupro no meio onde habita, sendo ainda acusada de adultério. Além disso, a rotina toma a conta daquele casal: a mulher pede esmolas, embriaga-se e retorna para a casa onde sofre violência da parte do marido. Quando o narrador suspende a rotina, por exemplo, um caso de enfermidade da senhora, momento oportuno para esperarmos alguma empatia entre os dois, dá-se exatamente o contrário de toda a afinidade: o homem teme perder o seu objeto, aquela que dá condições de sustentar a casa, deixando-o desamparado. 
As condições que forçam as conveniências do ajuntamento humano são superiores à espontaneidade do amor.

Como que num surto, o narrador nos faz sair da repetição e do tédio; algo inesperado ocorre. Certa vez, embriagada numa taverna, a mulher é protegida por um grupo de estudantes do ataque de homens que queriam agredi-la fisicamente. Inconsciente, ela é levada pelos rapazes para um local seguro, o necrotério, inicialmente com a aparência de capela. Sugere-se a intenção de ter momentos espontâneos de hilaridade, zombaria e entretenimento impulsionados pelo afeto. Subitamente a alegria é rompida, porque se nota a presença de um cadáver no local que lhes afeta a sensibilidade, causando um estranho sentimento de sobriedade, seriedade e frieza. No fim, algo lhe oferece a única satisfação não experimentada na narrativa: a morte do seu companheiro. Estilisticamente a mesma arquitetura se observa: as ações de simpatia são disparatadas e não encontram o seu elo. Somente a força das obrigações obteve êxito.

Em "Gavita", temos o caso trágico da bela moça que passa a cuidar da sobrinha, um bebê que adoece durante a narrativa. Ela fica tão apegada à criança que não se dá conta dos singelos interesses de um primo apaixonado. A bela moça, que tem todo o vigor da juventude, fica como que cega pelos mimos dedicados ao bebê. Diante desse quadro, é possível notar toda a exasperação do narrador ao ver a personagem, amada como uma filha, indiferente à paixão, pois ela não suspeita dos interesses de um primo que a ama em segredo. Nos primeiros parágrafos, o narrador exalta os dotes físicos da moça, tratando-a como se fosse uma filha; ele a compara demasiadamente com os seres espirituais. No entanto, essa comparação com os anjos, comportamento aparentemente inocente e natural dos pais, acaba por evidenciar a sua futura tragédia, pois o seu aspecto transcendente, ou a sua educação mimada de anjinho da família, teria feito com que ela perdesse certa noção da sua condição feminina, mulher que pode amar um homem.

Toda a família sofre com o mal-estar causado pela enfermidade do bebê; nesse momento são intensificados os zelos espiritualizantes de todos, como se ele fosse um objeto muito precioso no universo. A menina-moça assume a posição de enfermeira do enfermo. $\mathrm{O}$ narrador imagina que o Céu juntamente com ele sofre com a enfermidade da criança: "Toda a casa emudeceu agora. Assim deve ficar o céu, quando os anjos estão em rezas mentais"63. A menina, com seus quinze anos, esquece a sua natureza humana para evadir-se na espiritualização; com toques infantilizados e débeis, não está pronta para toda essa funcionalidade do amor e do seu corpo: "Na serenidade que lhe inunda o semblante já não se lê a feliz despreocupação de seus dias risonhos, lê-se a fé, essa rosa mística que só viceja nos corações fecundados pela dor" 64 . No momento em que o bebê se recupera da doença, o seu primo apaixonado é levado ao desespero por não ter sido notado, o que faz o narrador a lamentar a sina de um provável suicídio. Trabalha-se, com fina ironia, a educação burguesa: enquanto admira a sua moça como se fosse um anjinho, lamenta no fim a perdição de sua personalidade, que parece desprezar o corpo e as demandas dos sentimentos e ficar indiferente às investidas do primo.

A novela "Sapo" conta a história de Bruce, que contrai uma enfermidade psicológica após distanciar-se de um amigo muito querido e passar a viver isoladamente. Eles se desentenderam porque Ernesto assumiu uma amizade feminina. Quando Bruce investe em ciúmes contra o seu amigo, este Ernesto se torna passivo à sua reação: "O Ernesto abaixou os olhos, com os lábios trêmulos e brancos"65. Quando

\footnotetext{
63 VICTOR, Signos, 120.

${ }^{64}$ VICTOR, Signos, 122.

65 VICTOR, Signos, 133.
} 
Bruce decide deixar a mágoa para trás e se aproxima do desafeto para perdoá-lo, o examigo lhe trata com desdém: "Quando ele os viu, o Ernesto, sacudindo-se, ainda o apontava com o índice" 66 . O personagem chega a ter possibilidades de escapar do seu mundo alucinatório, ao sair da sua cidade ou obter novas amizades; no entanto, tais hipóteses são derrotadas na trama porque ele não tem forças para quaisquer iniciativas que possam salvá-lo do destino trágico. Suas perturbações mentais e suas escolhas ascéticas têm um fundamento: a cega obediência à vontade do pai falecido, que lhe pede em sonho para destinar a sua vida ao cumprimento de deveres religiosos. Suportando até os últimos limites a neurose, ou o conflito entre vontades antagônicas, a tendência humana e a celibatária, o herói sucumbe fatalmente no manicômio. Quando o pai real, na verdade um espírito, vem visitá-lo, Bruce está irremediavelmente louco no manicômio e não pode perceber a sua presença (ou pode?). Como podemos perceber, o narrador brinca com as ações de afeto que não encontram um correspondente. Porém, esse narrador mantém a sua coerência: tudo que é verdadeiro deve nascer da espontaneidade ou da transgressão daquilo que é artificioso, obrigatório e legalista.

\section{Conclusão}

A matéria poética de Victor essencialmente assume os principais paradigmas schopenhauerianos como veredas para a sua autorreflexão. $\mathrm{O}$ amor sexual, o impulso para a geração da vida, é o que determina o comportamento dos seres quando se dotam de sentimentos, que os seres humanos sublimam e espiritualizam, para se unir ao outro ser. Por isso, não há espontaneidade no ato de amar. A voz de oposição a esse terrível conceito de amor surgirá com a hipótese de um universo de relacionamentos, afetos e aproximações impossíveis.

O narrador revela fascínio e assombramento com essa realidade, sobretudo, uma aparente resignação. No entanto, acredita que tal proposição dispensou o amor e a necessidade de comunhão. Na verdade, fica evidente na obra que bastaria o sexo, conforme preconiza o filósofo: tanto é que o primeiro casal, após desprezar a inclinação ao afeto, é tomado por um "instinto bestial" 67 , a ponto de cometer sexo "cru, indecente e negro"68. Porém, o autor vai mais além. O que exatamente acontece é a incompatibilidade dos pares: no mundo de Victor, o amor sucumbiu e a procriação também acaba sendo gradativamente eliminada. Todos vão sendo gradativamente contagiados pela moléstia como uma praga que infestou o mundo: uns desprezam o contato íntimo e outros, os que não foram contaminados, ficam a sofrer pelo amor não correspondido. É possível escapar dos ditames da Vontade, como também preconiza Schopenhauer? Eis a reflexão de Nestor Victor, ilustre leitor do filósofo de Metafísica do Amor, ao adotar a negação da vontade e o convite para que os leitores dos seus contos compreendam o quanto isso pode ser benéfico ou maléfico para a humanidade.

\section{Referências}

\footnotetext{
66 VICTOR, Signos, 154 .

67 VICTOR, Signos, 14.

68 VICTOR, Signos, 14.
} 
BAKHTIN, Mikhail. Questões de literatura e estética. São Paulo: Editora 34, 2015 [1975].

BENJAMIM, Walter. O narrador. In: Obras escolhidas: Magia e técnica, arte e política. São Paulo: Brasiliense, 1994.

BOTTMANN, Denise Guimarães. Arthur Schopenhauer no Brasil (1887-2015). Universidade de Brasília, Brasil. Belas Infiéis, v.5, n.1, 2016, p.251-9.

BOSI, Alfredo. História concisa da literatura brasileira. São Paulo: Cultrix, 1995.

CHEVITARESE, Leandro. A eudemonologia empírica de Schopenhauer: a "liberdade que nos resta" para a prática de vida. Arthur Schopenhauer no Brasil: em memória dos 150 anos da morte de Schopenhauer. João Pessoa: Ideia, 2010. p.127-46.

CRUZ E SOUSA. João da. Cruz e Sousa: Obra completa. Org. Andrade Muricy. Rio de Janeiro: José Aguilar, 1961.

DEBONA, Vilmar. A noção de caráter adquirido: uma "liberdade" pela sabedoria de vida. Arthur Schopenhauer no Brasil: em memória dos 150 anos da morte de Schopenhauer. João Pessoa: Ideia, 2010. p.213-29.

MANN, Thomas. Schopenhauer, Nietzsche, Freud. Madrid: Alianza Editorial, 2000.

MICHAUD, Guy. Message poétique du Symbolisme. 3 volumes. Paris: Nizet, 1947.

MURICY, Andrade. O símbolo à sombra das araucárias (Memórias). Conselho Federal de Cultura, 1976.

MURICY, Andrade. Panorama do movimento simbolista no Brasil I. Brasília: MEC; INL, 1987 [1974].

PEYRE, Henri. A literatura simbolista. São Paulo: Cultrix, 1983 [1976].

SANTOS, Valci Vieira dos. Tragicidade nas poéticas de Cesário Verde e Cruz e Sousa. Campinas: Pontes Editores, 2017.

SANTOS, Kátia Cilene da Silva. A liberdade no pensamento de Schopenhauer. Arthur Schopenhauer no Brasil: em memória dos 150 anos da morte de Schopenhauer. João Pessoa: Ideia, 2010. p.273-301.

SCHOPENHAUER, Arthur. Metafísica do Amor. Metafísica da Morte. Tradução: Jair Barboza. São Paulo: Martins Fontes, 2000.

SCHOPENHAUER, Arthur. O mundo como vontade e representação. Tradução: M.F. Sá Correia. Rio de Janeiro: Contraponto, 2016.

SILVA, Luan Corrêa da. Metafísica prática em Schopenhauer. Tese de doutorado defendida no Programa de Pós-graduação em Filosofia da UFSC. Florianópolis-SC, 2017.

VICTOR, Nestor. Elogio do Amigo. São Paulo: Edição da "Revista do Brasil", Monteiro Lobato \& C. 1921.

VICTOR, Nestor. Obra crítica de Nestor Vítor I, III. Rio de Janeiro: Ministério da Educação e Cultura; Casa de Rui Barbosa, 1969, 1979.

VICTOR, Nestor. Signos. Rio de Janeiro: Tipografia Correia, Neves C., 1897. 